\title{
PROPHYLACTIC BLOOD PATCH DOES NOT PREVENT POST LUMBAR PUNCTURE HEADACHE
}

\author{
Richard J. Palahniuk and Maureen Cumming
}

\section{INTRODUCTION}

SINCE the introduction of the technique of treating post lumbar puncture headache by the injection of autologous blood into the epidural space by Gormley in 1960.' epidural blood patch has gained wide acceptance. ${ }^{2.3}$ The high success rate ${ }^{4}$ and the low incidence of complications in both short and long-term follow-up ${ }^{5}$ have reassured anaesthetists of the efficacy and safety of this technique in the management of a formerly difficult group of patients. It has also been suggested $^{6}$ that injection of autologous blood into the epidural space shortly after the dural puncture was performed (prophylactic blood patch) might prevent the development of post lumbar puncture headache. In order to determine the value of prophylactic blood patch, we studied the use of this procedure on our obstetrical anaesthesia service.

\section{MErhods}

During the three years from January, 1974 to December, 1976, 86 patients had accidental dural punctures using a \#16 Tuohy needle which were recognized during the induction of an epidural anaesthetic on our obstetrical anaesthesia service. In almost all cases, the epidural space was then properly identified and an epidural catheter was inserted to provide analgesia for the labor and delivery or Caesarean section. At the termination of the parturition, eleven patients received a prophylactic blood patch consisting of between five and $10 \mathrm{ml}$ of autologous blood injected through the epidural catheter. The decision to do a prophylactic blood patch was made by the attending anaesthetist. The patients were otherwise unselected. No patient complained of

Richard J. Palahniuk, M.D., Associate Professor of Anaesthesia and Obstetrics and Gynaecology, University of Manitoba; Director of Obstetric Anaesthesia, Health Sciences Centre. Maureen Cumming, R.N., B.Sc., Research Assistant. The Departments of Anaesthesia and Obstetrics and Gynaecology, University of Manitoba Health Sciences Centre, Winnipeg, Manitoba, Canada. R3E 0Z3.

Presented in part at the Society of Obstetric Anesthesia and Perinatology Meeting. Seattle, April, 1977.

Canad. Anaesth. Soc. J., vol. 26, no. 2, March 1979 headache before injection of the prophylactic blood patch.

Except for the prophylactic blood patch, all 86 patients were managed in a similar fashion following completion of their delivery. The epidural catheter was removed, the patient was placed on bed rest for a period of 12 to 30 hours, and adequate hydration was maintained orally or intravenously to a minimum of $150 \mathrm{ml}$ per hour. All patients received analgesics as necessary.

All patients were seen by one of us (M.C.) 12 to 30 hours after the delivery, assisted to the upright position, and the presence or absence of headache was noted. If no posiural headache occurred, the patient was allowed to be up at will with regular follow-up during her hospital stay to rule out later development of postural headache as well as other complications.

\section{RESULTS}

The mean ages and duration of bed rest for the patients who did and did not receive a prophylactic blood patch and those who did and did not develop headache are presented in Table 1 . Of the 75 patients who did not receive a prophylactic blood patch, 44 or 59 per cent developed a typical post lumbar puncture headache during their stay in hospital. The headache resolved with further conservative management in 23 , while 21 patients were treated with an epidural blood patch.

Of the 11 patients who did receive a prophylactic blood patch, six, or 54 per cent, developed a postural headache in the post-partum period. Of these, five were treated with a further epidural blood patch while one responded to bed rest and hydration alone.

None of the patients treated with a prophylactic blood patch suffered any apparent complications from the procedure on follow-up after five days. No further follow-up was done.

\section{Discussion}

The development of a post-lumbar-puncture headache in an otherwise healthy young parturient can be a difficult problem. Prolongation of hospitalization, pain and anxiety and the possible 132 
TABLE I

\begin{tabular}{|c|c|c|c|c|c|}
\hline & & \multicolumn{2}{|c|}{ No prophylactic blood patch } & \multicolumn{2}{|c|}{ Prophylactic blood patch } \\
\hline & & Headache & No headache & Headache & No headache \\
\hline $\begin{array}{l}\text { N } \\
\text { Age (yrs) }\end{array}$ & $\underset{\text { range }}{\operatorname{mean}( \pm S . D .)}$ & $\begin{array}{c}44 \\
24.8 \pm 4.9 \\
16-40\end{array}$ & $\begin{array}{c}31 \\
24.3 \pm 5.1 \\
17-41\end{array}$ & $\begin{array}{c}6 \\
27.8 \pm 7.0 \\
19-37\end{array}$ & $\begin{array}{c}5 \\
22.7 \pm 4.0 \\
18-25\end{array}$ \\
\hline $\begin{array}{l}\text { Duration of } \\
\text { bed rest (hrs) }\end{array}$ & $\begin{array}{l}\text { mean }( \pm S . D .) \\
\text { range }\end{array}$ & $\begin{array}{c}21.2 \pm 4.1 \\
12-30\end{array}$ & $\begin{array}{c}18.9 \pm 4.3 \\
12-27\end{array}$ & $\begin{array}{c}21.5 \pm 4.8 \\
12-24\end{array}$ & $\begin{array}{c}20.0 \pm 4.0 \\
12-24\end{array}$ \\
\hline
\end{tabular}

*Significantly less than the group that developed a headache, $\mathrm{P}<0.05$.

increased incidence of deep venous thrombosis associated with enforced bed rest can all lead to friction between the patient, her obstetrician and the anaesthetist. It is not difficult to understand why anaesthetists might be anxious to prevent post-lumbar-puncture headache. From this study, it appears that the incidence of postlumbar-puncture headache is unaffected by the prophylactic injection of blood through the epidural catheter. One possible explanation for the failure of prophylactic blood patching, when later treatment of the headache by blood patch is so successful, is that the tip of the catheter is likely to lie some distance from the puncture in the dura. Consequently the blood injected will not clot over the dural defect and will not prevent the cerebro-spinal fluid leak. Of course, the group of patients receiving a prophylactic blood patch (11) was quite small compared to the group not treated prophylactically (75), and it is possible that increasing the size of the group treated with prophylactic blood patch might show a lower (or higher) incidence of headache than the other group.

There were no complications resulting from prophylactic blood patch in this study. Despite the fact that there has never been a report of an epidural infection resulting from blood patching. anaesthetists must not become complacent, as the possible effects of an epidural abscess can be devastating. Since blood is an excellent culture medium and since epidural catheters frequently become contaminated during a continuous epidural anaesthetic, ${ }^{7}$ the injection of blood through an epidural catheter represents an increased risk of introducing infection into the epidural space and does not appear warranted.

\section{Summarr}

Of 86 patients in whom accidental punclure of the dura occurred during insertion of a needle for induction of epidural analgesia for labour and delivery, 11 received a prophylactic blood patch at the completion of delivery. Of the 75 patients with no prophylactic blood patch, 59 per cent developed posi-lumbar-puncture headache, while 54 per cent of those who had a prophylactic blood patch developed headache. The prophylactic blood patch appears to have no value in preventing post-lumbar-puncture headache in this small group of patients.

\section{RÉSUMÉ}

L'injection dans l'espace péridural de sang autologue avant le retrait du cathéter contribue(-i) à diminuer l'incidence de céphalées lor squ'il y a eu perforation accidentelle de la dure-mère au cours d'anesthésie péridurale? Cette mesure a été utilisée 1 I fois chez 86 parturientes ayant subi une telle perforation au cours d'une anesthésie péridurale effectuée durant le travail.

Cinquante-quatre pour cent de ces 11 malades ont présenté des céphalées posturales. Cinquante-neuf pour cent des 75 autres malades ont connu la même complication. Cette technique paraît donc sans valeur préventive.

\section{REFERENCES}

1. GormLEY, J.B. Treatment of post spinal headache. Anesthesiology $21: 565$ (1960).

2. DiGiovanni, A.J. \& Dunbar, B.S. Epidural injections of autologous blood for post-lumbarpuncture headache. Anesih. Analg. 49:268 (1970).

3. Doctor, N., DeZOYSA, S., Shah, R., MOd, K., \& Hussain, S.Z. The use of the blood patch for post-spinal headaches. Anaesthesia 3/: 794 (1976).

4. Ostheimer, G.W., Palahniuk, R.J., \& Shmider, S.M. Epidural blood patch for post-lumbarpuncture headache. Anesthesiology $41: 307$ (1974).

5. Agouleish, E., de la Vega. S., Blendinger, 1., \& Tiro, T. Long-term follow-up of epidural blood patch. Anesth. Analg. 54: 459(1975).

6. Balagot, R.C., LeE, T., LiU, C., Kwan, B.K., \& ECANOw, B. The prophylactic epidural blood patch. JAMA 228: 1369(1974).

7. abouleish, E., Amortegui, A.J., \& Taylor, F.H. Are bacterial filters needed in continuous epidural analgesia for obstetrics? Anesthesiology 46: $35 !$ (1977). 